\title{
PROČ NEPOTŘEBUJEME ČLOVĚKA PŘI LEGISLATIVNÍM VYMEZENÍ POJMU FYZICKÉ OSOBY?
}

\author{
KAREL BERAN*
}

\begin{abstract}
Why We Do Not Need a Human Being in the Legislative Definition of a Natural Person?

The aim of this article is to answer the question why we do not need "a man" in the legislative definition of a physical person. The author shows that in the Czech legal order we can identify two different possible approaches how to define according to the law what should be understood as a physical person. The first concept is based on a man to whom belong obligations and rights, while the latter concept is based on the ability to be a bearer of rights and obligations which belong not to a man, but to a physical or juristic person. The author believes that the second construction of a person is based on the pure legal science, which influenced precisely the construction of a person contained in the Civil Code of 1964 - this definition did not need "a man" to define the concept of a person.
\end{abstract}

Keywords: juristic Person, Person, Personified set of legal norms, point of imputation, Kelsen, Weyr

Klíčová slova: osoba, fyzická osoba, právnická osoba, personifikovaný soubor norem, bod přičitatelnosti, Kelsen, Weyr

DOI: $10.14712 / 23366478.2017 .26$

\section{ÚVOD}

Legislativní zakotvení pojmu fyzické osoby se v českém právním řádu poměrně často měnilo. Současné zákonné vymezení tohoto pojmu vychází zjednodušeně řečeno z toho, že člověk má býti považován za osobu. „Osoba“ je tak vymezována pomocí člověka. Za účinnosti občanského zákoníku z roku 1964, tj. zákona č. 40/1964 Sb., občanský zákoník (dále jen ObčZ 1964) však byl tento pojem konstruován zcela jinak. ObčZ 1964 totiž vlastně nestanovil, co osoba je, nýbrž pouze ř́kal, odkdy fyzická osoba nabývá způsobilosti $\mathrm{k}$ právům a povinnostem. $\mathrm{V}$ českém právním řádu tak můžeme identifikovat dvě různá pojetí, jak přistoupit $\mathrm{k}$ legislativnímu vymezení pojmu osoby: první vychází z člověka, kterému náleží práva a povinnosti, a tudíž je považován za osobu, druhé naopak vychází ze způsobilosti mít práva a povinnosti, které však nenáleží člověku, nýbrž fyzické nebo právnické osobě.

* Autor působí jako docent na katedře teorie práva a právních učení Právnické fakulty UK v Praze. Tato stat' byla zpracována v rámci programu Progres Q04 Právo v měnícím se světě. 
Domnívám se, že druhé zmiňované pojetí osoby lze chápat jako praktickou aplikaci poznatků, ke kterým dospěla ryzí nauka právní. Dlužno však podotknout, že náhled ryzí nauky právní na osobu nebyl jednotný. K této otázce se vyslovil jak Hans Kelsen, tak František Weyr, jejich pojetí však byla poněkud odlišná. Oba sice vycházejí z úvahy, že osoba představuje „bod přičitatelnosti“, resp. personifikovaný soubor právních norem, rozdíl mezi nimi však spočívá zejména v tom, jaký význam má chování člověka právě ve vztahu $\mathrm{k}$ tomuto personifikovanému souboru právních norem. $\mathrm{Z}$ těchto důvodů je třeba objasnit, co vlastně čistá právní věda pod osobou rozumí. Pokud chápeme osobu jako personifikovaný soubor právních norem, potom narážíme na problém subjektivního práva. Osoba je totiž tradičně chápána jako nositel subjektivních povinností a práv. Jestliže je osoba chápána jako „soubor právních norem“, je třeba také vysvětlit pojetí subjektivního práva jako právní normy.

Odpověd' na výše uvedené otázky by pak měla napomoci k porozumění tomu, jak ovlivnila ryzí nauka právní konstrukci osoby v českém právním řádu a proč jsme nepotřebovali (a možná stále nepotřebujeme) člověka při legislativním vymezení pojmu fyzické osoby.

\section{CO BYLO A JE OSOBOU PODLE PLATNÉHO PRÁVA ČR?}

Odpověd’ na otázku „kdo“, resp. „,co“ se de lege lata považovalo za osobu, se měnila tak, jak se měnil právní řád v souvislosti s přijímáním a rušením občanských zákoníků platných na území ČR. Nejstarší úpravu nalézáme v císařském patentu č. 946/1811 Sb. z. s., kterým byl přijat Všeobecný občanský zákoník (dále jen ABGB). Tento kodex u nás platil od roku 1811 do roku 1950, kdy byl nahrazen zákonem č. 141/1950 Sb., občanský zákoník (dále jen ObčZ 1950). Tento, tzv. střední občanský zákoník, byl v účinnosti od 1. ledna 1951 do 1. dubna 1964, kdy nabyl účinnosti zákon č. 40/1964 Sb. občanský zákoník. Tento občanský zákoník byl po roce 1989 mnohokrát podstatně novelizován, (nejvýznamnější novelizace č. 509/1991 Sb. se př́mo týkala úpravy osob, kdy se namísto pojmu „občan“ znovu zavedl pojem „fyzické osoby“ a byl též vložen § 18, který se stal základem úpravy právnických osob). V roce 2012 pak byl přijat zákon č. 89/2012 Sb. občanský zákoník (dále jen ObčZ), který vstoupil v účinnost dne 1. 1.2014 a představuje tak v současnosti platné a účinné právo na území ČR. ${ }^{1}$

První civilní kodex platný na našem území vycházel při vymezení osoby z člověka, když bylo (a v Rakousku stále je) v § 16 ABGB stanoveno, že „každý člověk má vrozená, již rozumem poznatelná práva, a nutno jej tudiž považovati za osobu. Otroctví nebo nevolnictví a $k$ tomu se vztahujici výkon moci nejsou v těchto zemích

K tomu srovnej THÖNDEL, A. K.: Stručný historický vývoj občanského práva na českém území. In DVOŘÁK, J. - ŠVESTKA, J. - ZUKLÍNOVÁ, M. et al.: Občanské právo hmotné, sv. 1., Praha: Wolters Kluwer, 2013, s. 82 an. 
dovolena. “2 Za základ úpravy právnických osob pak byl považován § $26 \mathrm{ABGB}$, který stanovil, že ,,vzájemná práva členů dovolené společnosti jsou určována smlouvou nebo účelem a zvláštními predpisy o nich vydanými. Naproti jiným osobám použivaji dovolené společnosti zpravidla stejných práv jako jednotlivé osoby. Nedovolené společnosti jako takové nemaji práv ani proti členům ani proti jiným osobám a nejsou zpưsobilé práv nabývati. Nedovolené společnosti jsou však ty, které jsou politickými zákony zvláště zakázány, nebo př́čí se zřejmě bezpečnosti, veřejnému pořádku nebo dobrým mravìm."3

ObčZ 1950 se stejně jako ABGB ještě zmiňoval o člověku, zavedl však již jako zákonný termín „osobu fyzickou“. Fyzická osoba byla totiž přímo obsažena v marginální rubrice uvozující § 4, který stanovil: „Zpưsobilost člověka mít v mezich právního řádu práva a povinnost vzniká narozením a zaniká smrtí. "Pokud jde o právnické osoby, stanovil ObčZ 1950 v § 18, že ,, (1) způsobilost k právům a povinnostem mohou mít i osoby rozdilné od osob fysických - osoby právnické. (2) K vzniku právnické osoby, která nebude zřizena prímo zákonem, je třeba, aby byla zřizena orgánem $k$ tomu přislušným anebo s jeho přivolením. "

V ObčZ 1964 již „člověka“ stejně však jako „fyzickou osobu“ vůbec nenalézáme, když bylo v $\$ 7$ stanoveno, že ,,(1) zpưsobilost občana mit práva a povinnosti vzniká narozením. Tuto způsobilost má i počaté ditě, narodí-li se živé. (2) Smrtí tato zpưsobilost zanikne. Jestliže smrt nelze prokázat předepsaným způsobem, soud fyzickou osobu prohlásí za mrtvou, zjisti-li její smrt jinak. Za mrtvou soud prohlásí také nezvěstnou fyzickou osobu, lze-li se žretelem ke všem okolnostem usoudit, že již nežije. "V návaznosti na novelu č. 509/1991 Sb. však byl pojem „občan“v roce 1991 znovu nahrazen pojmem fyzická osoba ${ }^{4}$ a zároveň byl v tomto roce nově vložen $§ 18$, který stanovil, že ,, (1) způsobilost mít práva a povinnosti mají i právnické osoby. (2) Právnickými osobami jsou a) sdružení fyzických nebo právnických osob, b) účelová sdružení majetku, c) jednotky územní samosprávy, d) jiné subjekty, o kterých to stanoví zákon. “

Platný a účinný občanský zákoník se při vymezení pojmu osoby opět vrátil k člověku, když ve svém § 19 odst. 1 stanoví, že ,,každý člověk má vrozená, již samotným rozumem a citem poznatelná prírozená práva, a tudiž se považuje za osobu. Zákon stanoví jen meze uplatňování prírozených práv člověka a způsob jejich ochrany. "Zároveň však v $§ 15$ odst. 1 ObčZ též stanoví, že ,právní osobnost je zpuisobilost mit v mezich právního rádu práva a povinnosti. "Právní osobnost ovšem nenáleží jen osobám fyzickým, nýbrž i osobám právnickým. Ty jsou pak vymezeny v § 20 ObčZ, který v odst. 1

2 „Jeder Mensch hat angeborne, schon durch die Vernunft einleuchtende Rechte, und ist daher als eine Person zu betrachten. Sclaverey oder Leibeigenschaft, und die Ausübung einer darauf sich beziehenden Macht, wird in diesen Ländern nicht gestattet. "

3 „Die Rechte der Mitglieder einer erlaubten Gesellschaft unter sich werden durch den Vertrag oder Zweck und die besondern für dieselben bestehenden Vorschriften bestimmt. Im Verhältnisse gegen Andere genießen erlaubte Gesellschaften in der Regel gleiche Rechte mit den einzelnen Personen. Unerlaubte Gesellschaften haben als solche keine Rechte, weder gegen die Mitglieder, noch gegen Andere, und sie sind unfähig, Rechte zu erwerben. Unerlaubte Gesellschaften sind aber diejenigen, welche durch die politischen Gesetze ins besondere verbothen werden, oder offenbar der Sicherheit, öffentlichen Ordnung oder den guten Sitten widerstreiten. “

4 V dalším textu budu vycházet z posledního účinného znění ObčZ 1964, který pracoval s pojmem fyzické osoby. 
stanoví, že „právnická osoba je organizovaný útvar, o kterém zákon stanoví, že má právni osobnost, nebo jehož právní osobnost zákon uzná. Právnická osoba může bez zřetele na předmět své činnosti mít práva a povinnosti, které se slučují s její právní povahou. "Z hlediska legálního vymezení osoby je však podstatný i $§ 17$, který stanoví, že „,(1) práva může mít a vykonávat jen osoba. Povinnost lze uložit jen osobě a jen vi̊či ní lze plnění povinnosti vymáhat. (2) Zř́dí-li někdo právo nebo uloži-li povinnost tomu, co osobou není, přičte se právo nebo povinnost osobè, které podle povahy právního prípadu náleži. “ Jakož i § 18, ve kterém je stanoveno, že ,, osoba je fyzická, nebo právnická “.

Jak je vidět, pojmové vymezení osoby se v každém z výše jmenovaných občanských zákoníků lišilo, a to jak pokud se týče osoby fyzické, tak i pokud jde o osobu právnickou. Nápadný a doslova očividný rozdíl v pojetí osoby, tak jak bylo stanoveno nejprve v ABGB, ObčZ 1950, jakož i v současnosti platném občanském zákoníku na straně jedné a v ObčZ 1964, spočívá ve vztahu k člověku. V ObčZ 1964 totiž člověk při vymezení osoby vůbec nefiguruje. Domnívám se, že to není náhoda. Domnívám se, že občanský zákoník z roku 1964 byl ovlivněn právním normativismem a také tím, jak právní normativismus osobu chápe. K tomu, abych tuto domněnku potvrdil, či vyvrátil, je však třeba objasnit, co znamená být osobou z hlediska ryzí nauky právní.

\section{JAK CHÁPE OSOBU „RYZÍ NAUKA PRÁVNÍ“?}

Podle Kelsena: 5 „být osobou“ je totožné s tím mít právní povinnosti a subjektivní práva. Osoba jako nositel povinností a práv není ničím odlišným od povinností a práv - tak jako strom, který má kmen, větve a květy, není hmotou rozdílnou od kmene, větví a květů, ale je pouze souhrnem těchto prvků. Fyzická nebo právnická osoba, která „mác povinnosti a práva jakožto jejich nositel, je těmito povinnostmi a právy - souhrnem právních povinností a práv, kterýžto souhrn je obrazně vyjádřen v pojmu „osoba“. Osoba je však jen personifikací této jednoty. ${ }^{6}$

Z toho plyne, že fyzická osoba je pouhou konstrukcí právního myšlení. Nejen právnická, nýbrž i fyzická osoba je zcela odlišná od pojmu člověka v jeho fyzické existenci. $\mathrm{Z}$ těchto důvodů musí být i fyzická osoba ve skutečnosti „osobou právnickou“. Z toho logicky vyplývá, že mezi fyzickou a právnickou osobou nemůže existovat zásadní koncepční rozdíl. ${ }^{7}$ Kelsenova argumentace je následující: ${ }^{8}$ „Jestliže v prípadě právnické osoby mohou být práva a povinnosti ,neseny“ něčím, co není člověkem, tak i tzv. fyzická

5 KELSEN, H.: Reine Rechtslehre. 2. Auflage. Wien: Veralg Franz Deuticke, 1960, s. 177.

6 „,Die Person als, Träger'von Rechtspflichten und subjektiven Rechten ist nicht etwas von den Rechtspflichten und subjektiven Rechten Verschiedenes, als deren Träger die Person dargestellt wird: so wie ein Baum, von dem man in einer substantivischen Sprache, die der Ausdruck eines substanzialisierenden Denkens ist, sagt, daß er einen Stamm, Äste, Zweige, Blätter und Blüten hat, nicht eine von diesem Stamm, diesen Ästen, Zweigen, Blättern und Blüten verschiedene Substanz, sondern nur der Inbegriff, die Einheit dieser Elemente ist. Die physische oder juristische Person, die Rechtspflichten und subjektive Rechte-als deren Träger - ,hat', ist diese Rechtspflichten und subjektiven Rechte, ist ein Komplex von Rechtspflichten und subjektiven Rechten, deren Einheit im Begriff der Person figürlich zum Ausdruck kommt. Die Person ist nur die Personifikation dieser Einheit. “

7 KELSEN, H.: Allgemeine Staatslehre. Bad Homburg - Berlin - Zurich: Verlag Max Gehlen, 1966 , s. 66.

8 KELSEN, H.: Reine Rechtslehre. Op. cit., s. 176-177. 
osoba, která má práva a povinnosti (a co také musí mít právnická osoba společného s osobou fyzickou, nebot' obě jsou ,, osoby “ jako ,nositelé “ práv a povinností), nemüže být člověkem, který je v tomto prípadě „,nositelem“, ale něčím, co maji člověk a právnická osoba společného."9

To, že člověk je nebo má právní osobnost, neznamená nic jiného, než že něco z jeho jednání a opomenutí tvoří nějakým způsobem obsah norem. Proto také vzhledem k rozlišování mezi člověkem a osobou není správné tvrzení, že právo opravňuje nebo zavazuje osoby. Kdo je zavázán a oprávněn, jsou lidé. Lidské chování tvoří obsah norem, a tím i obsah povinností a práv. Lidské jednání se tak podle Kelsena stává součástí obsahu normy. „Ve skutečnosti však právní osoba neni samostatným subjektem existujicím mimo své povinnosti a práva, ale je jejich personifikovanou jednotou, nebo-li - vzhledem $\mathrm{k}$ tomu, že povinnosti a práva jsou právními normami-personifikovanou jednotou souboru právnich norem." 10

Weyr však v této souvislosti upozorňuje na jistý rozpor v Kelsenových tvrzeních. Kelsen totiž podle Weyra na jednu stranu žádá, abychom př́sně odlišovali mezi ,„̌lověkem“ a „osobou“ zároveň si je však vědom jisté neoddělitelnosti těchto pojmů, když ř́ká: „,Jak povinováni, tak oprávněni mohou být pouze lidé, kteři splňují zcela konkrétní, podle rozdilných právních řádi̊ odlišné podminky; tj. napřr. konkrétni věk, rozumovou vyspělost, pro určitá oprávněni a určité povinnosti také konkrétni pohlavi nebo pưvod atd. V těchto př́padech se však jen jedná o lidské chováni označované jako skutková podstata nebo obsah normy." 11

Právě v tom spatřuje Weyr náznak, že Kelsen opouští původní zásadní dualistickou koncepci mezi světem, jaký je, a světem, jaký býti má. Podle Weyra však v normativním světě není místo pro fyzické jednotlivce, nýbrž pouze pro normativní body přičitatelnosti. Proto také Weyr ${ }^{12}$ setrvává důsledně na svém rozlišení pojmu subjektu $\mathrm{z}$ hlediska „abstraktní normologie“ a z hlediska aplikace práva. Podle Weyra si „logický pojem ,nositele‘ subjektivnich povinností a práv dlužno představovat jako pouhé abstraktum,

9 „,Wenn im Falle der juristischen Person Rechte und Rechtspflichten von etwas, getragen 'werden können, was nicht Mensch ist, kann auch im Falle der sogenannten physischen Person das, was die Rechte und Rechtspflichten ,trägt' und was die physische Person mit der juristischen gemeinsam haben muß, da doch beide als, Träger' von Rechten und Rechtspflichten Person sind, nicht der Mensch sein, der der in Frage kommende Träger ist, sondern etwas, was der Mensch ebenso hat wie die als juristische Personen angesprochenen Gemeinschaften. “

10 K tomu srovnej: „Es heißt: das Verhalten dieses Menschen ist Inhalt der Rechtsnormen. Das Verhalten einer Person ist nie Inhalt der Rechtssätze. Nur das Verhalten von Menschen. Und nur dadurch, daß eines Menschen Verhalten Inhalt von Rechtsnormen wird, können diese Inhalte auf die Einheit eines Systems von Rechtsnormen bezogen werden, kann die Person - als Personifikation dieser Einheit - Rechtspflichten und Berechtigungen, haben', so wie eben ein System, eine Ordnung, Inhalte hat. Eben darum kann wohl der Mensch, kann aber nicht die Person berechtigt und verpflichtet werden. Denn die Person berechtigen oder verpflichten hieße: Rechte berechtigen, Pflichten verpflichten, kurz: Normen normieren. Die Begriffe Person und Mensch verhalten sich zueinander wie Form und Inhalt. " (KELSEN, H.: Allgemeine Staatslehre. Op. cit., s. 64.)

11 Sowohl verpflichtet als auch berechtigt werden nur Menschen, die ganz bestimmte, nach den verschiedenen Rechtsordnungen verschiedene Bedingungen erfüllen; so ein bestimmtes Alter, der Vollgebrauch der Vernunft, für gewisse Berechtigungen und gewisse Pflichten ein bestimmtes Geschlecht oder Abstammung von bestimmten Menschen usw. Es handelt sich hier um die nähere Bestimmung des als menschliches Verhalten bezeichneten Tatbestandes oder Norminhaltes. (KELSEN, H.: Allgemeine Staatslehre. Op. cit., s. 64.)

12 WEYR, F.: Teorie práva. Brno - Praha, 1936, s. 112 n. 
jemuž ve vnějším světě nic neodpovídá a jež je jakýmsi geometrickým bodem, $k$ němuž vede právní rád jednotlivé povinnosti. "13 Ze svrchovanosti právního řádu plyne, že za tento bod může označit cokoli. To znamená, že právní řád může spojit s kterýmkoli kusem vnějšího světa, ba i s pouhou představou něčeho, co ve vnějším světě neexistuje, právní subjektivitu. $\mathrm{K}$ tomuto abstraktu vede právní rád jednotlivé povinnosti a vztah mezi tímto bodem a objektem jednotlivých povinností nazývá Weyr stejně jako Kelsen „prričitatelností“.

Subjektem práva ve Weyrově koncepci je tak ten, kdo je povinen uskutečnit normu, tj. obsah toho, co býti má. ${ }^{14} \mathrm{Z}$ normativního hlediska tento subjekt musí být rovněž abstrakcí - bodem přičitatelnosti. „Tento povinnostní subjekt se stává v právní teorii tzv. právní (právnickou) osobou." 15 Podle Weyra si je však třeba uvědomit, že pojem osoby (persony) je ryze normativní. V reálném světě neexistují žádné osoby, ani právnické, ani fyzické. „Normativní pojem osoby může pak pouze znamenati bud' normotvưrce, nebo povinnostni subjekt." $16 \mathrm{~V}$ obou př́padech jde o subjektivizaci, čili o subjektivní pojetí normy. „Na misto objektivni normy (to, co býti má) nastupuje bud” normotvưrce (ten, kdo chce, že něco být má), nebo povinnostni subjekt (ten, který jest povinen, odpovéden za to, co má býti)." ${ }^{17}$ Avšak předmět se nemění, subjektivisticky konstruovaná norma (jakožto normotvorný nebo povinnostní subjekt) zůstává svou podstatou stále normou. ${ }^{18}$

\section{SUBJEKTIVNÍ PRÁVO JAKO PRÁVNÍ NORMA}

Pojetí „osoby“ jako personifikace souboru právních norem může působit matoucím dojmem. Povinnosti a práva, jichž je osoba nositelem, totiž v současnosti nechápeme jako právní normy, nýbrž jako subjektivní povinnosti a práva. K pochopení normativní koncepce právního subjektu je proto nutné osvětlit koncepci subjektivního práva jako právní normy. To není tak jednoduché, jak by se na první pohled mohlo zdát. Náhled ryzí nauky právní na subjektivní právo se totiž měnil stejně jako normativní nauka sama. Rozlišujeme tak dvě etapy, které odděluje Merklovo učení o stupňovité výstavbě právního řádu.

První etapu charakterizuje převážně statický postoj, při kterém se jeví právní řád jako „,něco hotového, strnulého, jež nezná a nemůže znát změn... "19 Tuto koncepci nalézáme v ranějších dílech jak u Kelsena v jeho díle Hauptprobleme der Staatslehre (Tübingen 1911), tak u Weyra v jeho Základech filosofie právní (Brno 1922). V této etapě vyvozoval

13 WEYR, F.: Základy filosofie právní. Brno, 1920, s. 173 n.

14 WEYR, F.: Teorie... Op. cit., s. 112.

15 Tamtéž.

16 Tamtéž, s. 113.

17 Tamtéž.

$18 \mathrm{Z}$ tohoto hlediska lze také pochopit normativistické ztotožnění státu s právním řádem. Vyjdeme-li totiž z normativního východiska identifikace normotvorného, resp. povinnostního subjektu s právní normou, potom normativní poznávání státu musí ve skutečnosti znamenat normativní poznávání jeho právního řádu.

19 WEYR, F.: Základy... Op. cit., s. 138. 
Kelsen ještě subjektivní právo z práva objektivního a spatřoval v něm subjektivní jevovou formu (,Erscheinungsform ") právní normy. ${ }^{20}$ Ta pro něj představovala cosi stálého, zatímco subjektivní právo vznikalo teprve tehdy, když to připustila norma objektivního práva jako právně relevantní skutečnost. K subjektivizaci právní normy v oprávnění tak mohlo dojít pouze za předpokladu, že norma vyžadovala jako podmínku pro svoji aplikaci projev vůle jednajícího - tj. naprííklad žalobu. Jen tehdy mohl nastat následek předpokládaný normou (v podobě exekuce nebo trestu). $\mathrm{V}$ této době ještě Kelsen tvrdil, že subjektivní právo je právní pravidlo $v$ jeho vztahu k osobě, na jejíž dispozici je učiněna závislou podmíněná vůle státu $\mathrm{k}$ následku bezpráví, vyslovená $\mathrm{v}$ právním pravidle. Mezi právním pravidlem a subjektivním právem tak není identita. ${ }^{21}$ Právní pravidlo je permanentní, kdežto trvání subjektivního práva je omezené. V této fázi dokonce ani Weyr nepřipouštěl normativní konstrukci pojmu oprávnění. Subjektivní právo totiž chápal jako problém aplikace práva. Aplikace je ale ze statického pohledu změna a pojem subjektivního práva by tedy přesahoval daný normativní rámec do čehosi ,,metanormativního “.22 Problém aplikace a intertemporality práva tak vyřešil až Merkl ve svém , učení o stupñovité výstavbě právního rádu “. ${ }^{23}$ Principy derogace a delegace mu umožnily vidět právní rád dynamicky, tedy jako hierarchicky usporádaný soubor norem, ve kterém stále nejrůznější možné normy vznikají, mění se nebo zanikají. To, co normativní teorie dříve považovala za právní skutečnost, se nyní stalo odvozenou právní normou. V návaznosti na to přestal Kelsen ${ }^{24}$ odvozovat subjektivní právo z objektivního, ale právo chápal výhradně jako právo objektivní. Subjektivní právo pro něj představovalo eventuální, nikoli však vždy nezbytně nutnou podmínku pro vznik, ,individuální normy soudního rozsudku“. Projev vůle osoby byl právě onou podmínkou, bez které by rozsudek nemohl být vydán. Subjektivní právo se tak jeví jako zajištění účasti na normotvorbě vedoucí ke konkrétní normě. Proto Kelsenova koncepce umožňuje převést každé právo na právo objektivní.

Rovněž Weyr objektivizoval všechno právo. Navíc ale nahradil původní statické rozlišení objektivního a subjektivního práva rozlišením novým, dynamickým. To proti sobě klade obecné a konkrétní normy. „Subjektivní právo je tedy normou, ovšem normou konkrétní a odvozenou. “25 Mohlo by se tak zdát, že mezi Kelsenem a Weyrem není v chápání subjektivního práva rozdíl. Tento rozdíl však existuje. Výslovně na něj upozornil český administrativista Jan Matějka, jenž kritizoval ,, hlasy, které popíraji nutnost, poprípadě vỉbec možnost konstrukce subjektivního práva “. ${ }^{26}$ Tím měl na mysli zejména Kelsenovu koncepci subjektivního práva jako „konkretizaci obecné normy“.

Podle Matějky totiž Kelsen vycházel z nesprávného předpokladu, ,že rozdil mezi subjektivním a objektivním právem tkví stále svými kořeny v přirozenoprávním ovzduší

20 KELSEN, H.: Hauptprobleme der Staatslehre. Tübingen, 1911, s. 626.

21 Tamtéž.

22 K tomu srovnej WEYR, F.: Základy... Op. cit., s. 138.

23 MERKL, A.: Die Lehre von der Rechtskraft, entwickelt aus dem Rechtsbegriff. Leipzig - Wien, 1923.

24 KELSEN, H.: Reine Rechtslehre. Leipzig - Wien, 1934, s. 47-52.

25 WEYR, F.: Teorie... Op. cit., s. 171 n.

26 MATĚJKA, J.: Pojem veřejnoprávní korporace. In Sborník věd právních a státních. Praha, 1929, s. 15. 
konstruujícím vrozená, nezadatelná práva jednotlivcova, jež mají tvoriti absolutní hranici proti positivnímu právu. “27 Tak tomu ale podle Matějky není. Když se praví, „že subjektivní právo je odvozeno z objektivního práva, "znamená to, že není možný vznik subjektivního práva, aniž by první bylo právo objektivní, a také, že subjektivní právo neexistuje před právem objektivním. Právo však nestačí jen poznávat, nýbrž je třeba jej i aplikovat. Podle J. Matějky tak F. Weyr správně dokazuje, „že k celkovému poznání právního řádu je potřebi celé řady pojmů, které nelze viobec konstruovati (definovati) normativně, v přední radě pojmu subjektivního práva (oprávnění) a jeho subjektu." 28

Tomuto pojetí subjektivního práva se blíží i koncepce českého civilisty Jana Krčmáře.$^{29}$ Podle něj je funkcí právního řádu úprava lidského soužití a ochrana důvodných zájmů jedněch proti druhým. Proto, aby bylo těchto cílů dosaženo, ukládá právní rád lidem povinnosti, když jsou naplněny určité skutkové okolnosti. $V$ prŕípadě porušení takto uložených povinností ukládá právní pravidlo sankci. Krčmář uvádí, že „,starší právnická terminologie charakterizovala toto uspořádání tak, že se přiznává nositeli zájmu oprávnění (subjektivni právo). "Novější terminologie pak rozeznává mezi nárokem a subjektivním právem. ,Nárok se priznává tomu, na koho náleží iniciativa vymoci, aby byl odčiněn nastalý již stav, príčící se právní norměe. "Subjektivní právo je tak podle Krčmáře ,, určeno jako situace vytvořená právními normami, která, porušili se povinnosti uložené normami, dá vzniknout nároku. "30

Jaká je tedy konstrukce osoby z hlediska čisté právní vědy? Celkem jednoduchá: Každá osoba, tedy i ta, kterou považujeme za přirozenou a jejímž „,substrátem“ je člověk, je osobou právnickou. Jak fyzická, tak právnická osoba totiž není ničím jiným než „personifikací souboru právních norem“, jejichž obsah (tedy obsah právních norem) svým chováním vždy naplňuje jednání lidských bytostí. I v př́padě právnické osoby (míněno v tradičním slova smyslu) dochází k naplňování obsahu právních norem vždy a pouze jednáním lidských bytostí. Jde však o to, že se toto jednání nepřičítá tomu, co nazýváme osoba přirozená nebo fyzická, nýbrž osobě právnické. Je tomu tak proto, že člověk, který jedná v př́ípadě osoby právnické, jedná jako její orgán a jeho jednání je tak přičítáno osobě právnické.

Můžeme tedy uzavřít, že vše, co je jako osoba označeno, bez ohledu na to, zdali se jedná o fyzickou, či právnickou osobu, ve skutečnosti neexistuje. Jedná se o pouhý pomocný pojem právní vědy, který je zde proto, aby vysvětlil složitou právní situaci antropomorfní metaforou. $V$ právní vědě však obvykle nehovoříme o metaforách, nýbrž o právních pojmech. Důvod, proč potřebujeme osobu jako zvláštní pojem, vysvětlil Sedláček, když zavedl rozlišení mezi pojmy čistými (formální podmínky právnického poznávání), obsahovými (obsah práva) a podle něj též nově „systematickými““ (systematika právního řádu vzhledem $\mathrm{k}$ individuálním morálním, hospodářským či jiným zájmům). Pojem subjektu práva tak můžeme chápat nejen čistě formálně či obsahově, ale

\footnotetext{
27 Tamtéž, s. 18.

28 Tamtéž, s. 20.

29 KRČMÁR̆, J.: Právo občanské I. Praha, 1927, s. 69n.

30 Tamtéž.
} 
rovněž nám může poodhalit hranice normativního systému vůči systémům jiným - coby pojem systematický. ${ }^{31}$ Proto je také podle Weyra ${ }^{32}$ pojem právní osobnosti nejen teoretickým pojmem regulativním, nýbrž i systematickým. Osoba v právu jako systematický pojem nás pak navádí $\mathrm{k}$ praktické funkci normy, která spočívá $\mathrm{v}$,jeji aplikovatelnosti ve světě vnějš́m - povinnosti může mit pouze jednotlivý člověk (ale ne každý, srov. např. šilence, nemluvňata apod.) jako fyzická jednotka biologická, protože jen on jest s to, aby si je psychologickým pochodem uvédomil a podle nich jednal, tj. je plnil. “"33

\section{JAK OVLIVNILA ČISTÁ PRÁVNÍ VĚDA KONSTRUKCI OSOBY V ČESKÉM PRÁVNÍM ŘÁDU?}

V okamžiku, kdy byla vysvětlena normativní koncepce osoby jako personifikace souboru právních norem, je snad možné odpovědět na otázku, jak ovlivnila čistá právní věda konstrukci osoby v českém právním řádu.

V této souvislosti je třeba především podotknout, že jak Kelsen, tak Weyr tvořili svá díla v době, kdy bylo pojmové vymezení osoby obsaženo v § 16 ABGB, jenž stanovil, že , každý člověk má vrozená, již rozumem poznatelná práva, a nutno jej tudiž považovati za osobu. Otroctví nebo nevolnictví a k tomu se vztahujicí výkon moci nejsou v těchto zemích dovolena. "

Jestliže Hans Kelsen kritizoval pojetí osoby, podle kterého představuje „osoba“ právní substanci, které náleží práva a povinnosti jako její právní kvalita, mám za to, že implicitně kritizoval i pojmové vymezení osoby v § 16 ABGB. Totiž myšlenka, že ,fyzická nebo právnická osoba, která ,,má “ tyto právní povinnosti a subjektivní práva jako jejich nositel“, tak v sobě zahrnuje vztah mezi substancí a kvalitou. ${ }^{34}$

Toto východisko tradiční právní vědy ${ }^{35}$ považoval Kelsen za nepřesné, resp. nesprávné. Právní norma totiž nemůže determinovat člověka v celé jeho existenci. Člověk může být subjektem ,práva“ pouze k určitému vymezenému rozsahu jednání a zdržení se jednání. Tam, kde chování člověka není předmětem práv a povinností, není ani člověk v žádném vztahu k právnímu řádu.

Chyba tradičního právního uvažování spočívá podle Kelsena v tom, že hledá vždy „něco“, tj. určitou substanci, které práva a povinnosti náležejí. Proto je také lidské cho-

\footnotetext{
SEDLÁČEK, J.: Občanské právo československé. V̌̌eobecné nauky. Brno, 1931, s. 40n.

WEYR, F.: Teorie... Op. cit., s. 114.

3 Tamtéž.

4 K tomu srovnej: KELSEN, H.: Reine Rechtslehre. Op. cit., s. 177.

35 Pojem tradiční právní věda používám ve významu, v jakém jej používali právní normativisté v situacích, kdy se proti této „tradiční“ vědě vymezovali. Tímto pojmem nemá být řečeno, že se má právní nauka dělit na normativní teorii a tradiční právní vědu. V takovém případě by totiž mohly vzniknout pochybnosti o tom, co to vlastně je ,tradiční právní věda“. Nenormativistická sféra totiž nepochybně představuje v právní teorii řadu nejrůznějších proudů od volnoprávní školy po marxismus, přičemž ani jeden z uvedených směrů není v právní teorii „tradiční“. Pojem „,tradiční právní věda“, tak jak je použit a myšlen v tomto článku, má vyjádřit pouze to, že jde o všechny ostatní směry právní vědy, které nevycházejí ze striktního metodologického východiska ryzí právní nauky, kterým je odlišování toho, „,o je“, od toho, co „býti má“, přičemž předmětem zkoumání ryzí právní nauky je pouze to, co „býti má“, tj. právní normy a proto je ryzí. Zatímco všechny ostatní směry právní vědy takto striktní nejsou, a z tohoto hlediska jsou „tradiční“.
} 
vání (jako určitá kvalita) nesprávně pochopeno jako substance, tj. subjekt práv a povinností. ${ }^{36}$ Kelsen tvrdí, že tato konstrukce je příznačná pro primitivní mytologické uvažování, jež se vyznačuje právě tím, že každému objektu přiznává duši, která mu panuje (animismus). Tak tomu ale podle něj není: ,,Jestliže má být člověk předmětem právního poznání, musí vejít do práva. V právu však nenalézáme celého člověka jako takového, jakožto specifickou psychofyzickou jednotku se všemi jejími aspekty. V právu nacházíme pouze jednotlivá lidská jednání-s negativním předznamenáním označovaná jako „opomenuti“", která se jako podmínky nebo následky stávají součástí práva. Tak jako každý obsah může se také lidské jednání stát objektem právní vědy pouze jako obsah právní normy. " 37

Z toho plyne, že osoba existuje pouze potud, pokud „má“ povinnosti a práva, mimo ně osoba žádnou existenci nemá. Definovat fyzickou (přirozenou) osobu jako lidskou bytost je nesprávné, protože člověk a osoba nejsou jen dvěma rozdílnými pojmy, nýbrž i výsledky dvou na sobě zcela nezávislých způsobů chápaní. Pojem člověka vychází z jeho biologického a fyziologického bytí, a proto je i pojmem prírodních věd. Osoba je pojmem jurisprudence, právní vědy, spočívající v analýze právních norem.

Domnívám se, že právě tato úvaha byla důvodem, proč ObčZ 1964 v $§ 7$ zcela eliminoval člověka, když stanovil, že ,,(1) zpưsobilost fyzické osoby mít práva a povinnosti vzniká narozením. Tuto způsobilost má i počaté dítě, narodí-li se živé. “ $\mathrm{Na}$ rozdíl od § 16 ABGB zde nenalézáme, že ,člověk je osobou“, ale ani to, co stanovil § 4 ObčZ 1950, podle kterého ,způsobilost člověka mít v mezích právního řádu práva a povinnost vzniká narozením a zaniká smrtí. “ ObčZ 1964 mluví pouze o „fyzické osobě“ a její způsobilosti mít práva a povinnosti. Právě tím se ObčZ 1964 vyhnul problému, na který též upozorňoval Kelsen. Totiž, chápeme-li (fyzickou) osobu pouze jako soubor právních norem, potom nemůže dávat smysl ani obvyklé tvrzení, že osobě náleží práva a povinnosti. To by totiž znamenalo, že soubor povinností a práv má povinnosti a práva. Jednalo by se tak o nesmyslnou prázdnou tautologii. ${ }^{38}$

„Že je člověk subjektem práv, tedy subjektem práv a povinností, neznamená, jak bylo již zdůrazněno, nic jiného, než že lidské chování je obsahem právních povinností a subjektivních práv, tedy totéž, jako že člověk je osobou nebo že má osobnost. To, oč v obou připadech - fyzických i právnických osob - skutečně jde, je lidské chování, jehož obsahem jsou povinnosti a práva, která tvoři jednotu. Jelikož jsou tyto povinnosti a práva stanoveny právními normami - přesněji řečeno jsou právními normami - je problém osoby v posledni řadě problémem jednoty souboru právnich norem (normativního komplexu). “ 39

36 KELSEN, H.: Allgemeine Staatslehre. Op. cit., s. 63.

37 „Soll der Mensch zum Gegenstand juristischer Erkenntnis werden, muß er in das Recht eingehen. Allein nicht der ganze Mensch, nicht der Mensch als solcher, d. h. die spezifische Einheit der Biologie und Psychologie mit allen ihren Punktionen wird von der Rechtsordnung aufgenommen. Sondern nur einzelne menschliche Handlungen - mit negativen Vorzeichen ,Unterlassungen ' genannt - sind es, die als Bedingungen oder Folgen in das Rechtsgesetz Eingang finden. Wie jeder Inhalt, so kann auch menschliches Verhalten nur als Inhalt des Rechtssatzes zum Objekt der Rechtswissenschaft werden. " (KELSEN, H.: Allgemeine Staatslehre. Op. cit., s. 63.)

38 Tamtéž, s. 64.

39 „Daß der Mensch Rechtssubjekt, das heißt Subjekt von Rechten und Pflichten ist, bedeutet, wie im Vorhergehenden mit Nachdruck betont wurde, nichts anderes, als daß menschliches Verhalten Inhalt von Rechts- 
Legislativní řešení problému, o kterém se zmiňuje Kelsen, tak spočívá právě v tom, že se normativní text vůbec nebude zmiňovat o „substanci“ - tj. člověku, ale omezí se výlučně na to, co ona pomyslná substance ve skutečnosti je, tedy na povinnosti a práva. Po mém soudu není náhodou, že v § 7 ObčZ 1964 neříká, co fyzická osoba je, nýbrž jen to, kdy vzniká její způsobilost mít práva a povinnosti. Právě tím se vyhýbá definici kruhem, že osobě, kterou normativismus chápe jako povinnosti a práva, povinnosti a práva náležejí.

Obdobnou konstrukci jako v př́padě fyzických osob zvolil ObčZ 1964 i v případě osob právnických, když v $§ 18$ stanovil, že ,způsobilost mít práva a povinnosti mají i právnické osoby. "I v tomto př́padě se ObčZ 1964 vyhnul tomu říci, co právnická osoba je a soustředil se pouze na to stanovit, že jí náleží způsobilost mít práva a povinnosti.

ObčZ 1964 tak jak v př́ípadě fyzické osoby, tak v př́ípadě právnické osoby ve skutečnosti vůbec nestanoví, co je fyzická nebo právnická osoba. Pouze jim přisuzuje právní způsobilost a eventuálně stanoví, co je důvodem jejího nabytí. Pravdou sice je, že socialistická právní věda se k právnímu normativismu nehlásila, to však po mém soudu nevylučuje, že právě normativistické pojetí osoby mohlo být inspirací pro tvůrce ObčZ 1964. Stejně tak je ale možné, že se jedná o náhodu. At' už však byla inspirace tvůrců ObčZ 1964 jakákoliv, je jisté, že se pojmová vymezení osoby v ObčZ 1964 vyhnula pojetí osoby, která je chápána jako substance, jíž náleží práva a povinnosti jako její kvalita.

Jestliže se občanský zákoník z roku 2012 vrací k pojetí osoby tak, jak jej podával $\S 16$ ABGB (s tím že ,, vrozená práva člověka " nepoznávají Češi na rozdíl od Rakušanů pouze „rozumem“, nýbrž i „citem“), potom se ve skutečnosti vrací k tomu, co čistá právní věda kritizovala, $\mathrm{k}$ pojetí, které chápe povinnosti a práva jako substanci, jíž ovšem náleží povinnosti a práva jako její kvalita.

A to je i odpověd' na otázku, jak ovlivnila čistá právní věda konstrukci osoby v českém právním řádu. Domnívám se, že čistá právní věda ovlivnila právě onu konstrukci osoby, která byla obsažena v občanském zákoníku z roku 1964. Po mém soudu lze dokonce tvrdit, že pojetí osoby v ObčZ 1964 bylo pojetí normativistické.

Český občanský zákoník z roku 2012 se však vrátil k takovému pojetí osoby, jaké podávala tradiční právní věda a které také kritizoval jak Hans Kelsen, tak František Weyr. Skutečnost, že platný a účinný občanský zákoník vychází z toho, že fyzická osoba je člověk a právnická osoba organizovaný útvar, by mohla naznačovat, že normativní konstrukce osoby byla v právním řádu ČR zcela opuštěna. Úplně tomu tak ale po mém soudu není.

V českém občanském zákoníku totiž nalézáme nejen spojení osoby se světem reality, tj. s člověkem v př́padě fyzické osoby a s organizovaným útvarem v př́padě osoby právnické, nýbrž i spojení osoby se světem normativním. Spojení se světem, kde osoba není ničím odlišným od povinností a práv, které se jí přičítají. To plyne z § 17, který

pflichten und subjektiven Rechten ist, also dasselbe, wie daß ein Mensch Person ist oder Persönlichkeit hat. Was in beiden Fällen - der physischen wie der juristischen Person - tatsächlich vorliegt, sind menschliches Verhalten beinhaltende Rechtspflichten und subjektive Rechte, die eine Einheit bilden. Rechtsperson ist die Einheit eines Komplexes von Rechtspflichten und subjektiven Rechten. Da diese Rechtspflichten und subjektiven Rechte durch Rechtsnormen statuiert - richtiger: diese Rechtsnormen - sind, ist das Problem der Person in letzter Linie das Problem der Einheit eines Normenkomplexes. "(KELSEN, H.: Reine Rechtslehre. Op. cit., s. 176-177.) 
stanoví, že „,(1) práva může mít a vykonávat jen osoba. Povinnost lze uložit jen osobě a jen vůči ní lze plnění povinnosti vymáhat. (2) Zř́dí-li někdo právo nebo uloži-li povinnost tomu, co osobou není, přčcte se právo nebo povinnost osobě, které podle povahy právního prípadu náleži. “”

Domnívám se, že být osobou znamená v souladu s $\S 17$ být bodem přičitatelnosti povinností a práv, které osobě náležejí. Obávám se však, že než o promyšlenou koncepci a vědomý př́iklon k normativnímu pojetí se jedná spíše o „náhodu“. Pokud by totiž ObčZ 2012 vycházel z toho, že osoba je pouhý abstraktní bod přičitatelnosti, potom by stěží mohl zároveň stanovit, že touto osobou je člověk.

\section{ZÁVĚR}

Pojem osoby byl v českém právu legislativně vymezen celkem čtyřikrát - pokaždé trochu jinak. V zásadě však lze rozlišit dvě koncepce, na kterých bylo vymezení osoby v platném právu založeno. První z nich vychází z člověka, kterému náležejí práva a povinnosti. To je koncepce, kterou nalézáme v ABGB, ObčZ 1950 a potom zase znovu v občanském zákoníku, který je v ČR účinný od roku 2014. Druhou, odlišnou koncepci nacházíme v ObčZ 1964, který při vymezení pojmu osoby nevychází z člověka, nýbrž ze způsobilosti mít práva a povinnosti, která nenáleží člověku, nýbrž fyzické nebo právnické osobě.

Způsobilost mít práva a povinnosti, tj. právní subjektivita (resp. právní osobnost) je také východiskem uvažování o osobě pro právní normativismus. Jak Kelsen, tak Weyr chápou osobu jako abstraktní bod přičitatelnosti, nositele subjektivních práv a povinností, který je personifikován tím, že je označen jako osoba. Osoba je však pojmově něco zcela jiného než člověk, její existence je pojmově spjata s povinnostmi a právy, které této osobě náležejí. Kromě těchto povinností a práv osoba žádnou existenci nemá, a právě tím se liší od člověka. Chování člověka je tak pouze obsahem právních norem. To ale neznamená, že chování člověka lze považovat za osobu. Chování, respektive jednání člověka totiž může být přičítáno různým osobám, které s člověkem, resp. fyzickou osobou vůbec nemusejí korespondovat - tj. zejména v případě tzv. právnických osob.

Jednou ze zásadních a důležitých odlišností právního normativismu od tradiční právní vědy je jeho chápání subjektivních práv. Tradiční právní věda vychází z toho, že právní norma je obecná, což znamená, že se aplikuje na prŕípady stejného druhu neurčeného počtu. Právě tím se liší od subjektivního práva, které je konkrétní, respektive individuální, což znamená, že se vztahuje pouze na jeden jediný konkrétní individuální př́pad.

Právní normativismus však nechápe odlišnost mezi tím, co je „obecné“, a tím, co je „individuální“, jako nepřekonatelný rozdíl. Naopak si všímá toho, co mají subjektivní právo a právní norma společného. Tím je nutnost splnit to, co má být, at’ už je stanovena obecně, nebo individuálně. Z tohoto pohledu dává také logiku chápání subjektivního práva jako konkrétní (tj. individuální) a odvozené právní normy. Tím se také vysvětluje normativní koncepce osoby jakožto personifikace souboru právních norem. „Osoba“ tak 
představuje pouhý pomocný pojem, který je ovšem důležitý pro poznání systematiky právního řádu.

Jestliže právní normativismus vychází z úvahy, že „osoba“ ve světě reality neexistuje a znamená pouhou personifikaci souboru právních norem, potom nemůže dávat logiku ani tvrzení, že osobě, jakožto souboru povinností a práv, náležejí práva a povinnosti. Chce-li se zákonodárce vyrovnat s tímto problémem, potom se musí vyhnout tomu, aby řekl, co osoba je, zároveň a především však nesmí stanovit, že osobě náležejí povinnosti a práva.

Právě takové vymezení osoby bylo možné nalézt $\mathrm{v} \S 7$ ObčZ 1964, který stanovil, že „způsobilost fyzické osoby mít práva a povinnosti vzniká narozením. “ $Z$ tohoto ustanovení totiž neplyne nic jiného než to, že být fyzickou osobou ve skutečnosti znamená způsobilost mít práva a povinnosti, a kdy tato způsobilost vzniká. Obdobné koncepční východisko bylo zvoleno i v případě § 18 ObčZ 1964, pokud se týče právnických osob.

Z těchto důvodů se domnívám, že pojetí ObčZ 1964 (minimálně ve znění od roku 1991) bylo pojetím, které se vyrovnávalo s problémem souboru povinností a práv jakožto určité kvality, o které však zákon nikterak nestanovil, že se jedná o substanci (osobu), jíž tato kvalita náleží. Jestliže se tak občanský zákoník z roku 2012 navrátil k pojetí $\mathrm{ABGB}$, potom proti tomuto pojetí lze vznášet stejné námitky, se kterými př̌šli Kelsen a Weyr a které byly po mém soudu uspokojivě vyřešeny koncepcí, na níž byl založen občanský zákoník z roku 1964.

doc. JUDr. Karel Beran, Ph.D.

Univerzita Karlova, Právnická fakulta

beran@prf.cuni.cz 